\title{
PENGARUH KARET ALAM SIKLIK (CYCLIC NATURAL RUBBER) TERHADAP RONGGA ASPAL MODIFIKASI
}

\author{
W. Ritonga*, Irfandi \\ Jurusan Fisika, Fakultas MIPA, Universitas Negeri Medan, Indonesia
}

Diterima: 30 Januari 2016. Disetujui: 28 Maret 2016. Dipublikasikan: Juli 2016

\begin{abstract}
ABSTRAK
Penelitian ini bertujuan untuk mengetahui pengaruh karet alam siklik terhadap rongga aspal modifikasi. Tahapan peneltian meliputi pembuatan aspal modifikasi dengan menyampur aspal murni dengan karet alam siklik, pengujian persyaratan fisik aspal, pembuatan benda uji dan pengujian marshall. Berdasarkan pengujian sifat fisik aspal diperoleh data bahwa keseluruhan aspal modifikasi memenuhi persyaratan fisik aspal. Setelah pembuatan benda uji, dilakukan pengujian marshall untuk memperoleh rongga aspal meliputi VIM, VMA dan VFA. Nilai VIM pada penambahan 0 phr, 1 phr, 2 phr, 3 phr, dan 4 phr adalah 3,65\%, 5,41\%, $4,27 \%$, 3,84\%, dan 2,88\%. Nilai VMA sebesar 15,52\%, 17,26\%, 16,07\%, 15,80\%, dan 15,17\%. Nilai VFA sebesar $76,48 \%, 68,72 \%, 73,54 \%, 75,76 \%$, dan $81,34 \%$. Diperoleh kesimpulan bahwa karet alam siklik bisa dijadikan sebagai bahan memodifikasi aspal dan berpengaruh terhadap rongga aspal.
\end{abstract}

\section{ABSTRACT}

This research aimed to determine the effect of cyclic natural rubber (CNR) to cavity of modified bitumen. The steps of the research were mixing the pure bitumen with CNR, testing bitumen physical requirement, making the specimen, and testing the cavity of modified bitumen with marshall method. Testing showed that all the modified bitumen met the physical requirement. After making specimen, marshall method was used to determine the cavity of bitumen, including VIM, VMA, and VFA. VIM in addition of $0 \mathrm{phr}, 1 \mathrm{phr}, 2 \mathrm{phr}, 3 \mathrm{phr}$, and 4 phr was $3,65 \%, 5,41 \%, 4,27 \%, 3,84 \%$, and $2,88 \%$. The value of VMA was $15.52 \%, 17.26 \%, 16.07 \%$, $15.80 \%$ and $15.17 \%$. The value of VFA was $76.48 \%, 68.72 \%, 73.54 \%, 75.76 \%$ and $81.34 \%$. The conclusion of this study was CNR could be used as material for bitumen modified and had the effect on bitumen cavity.

(C) 2016 Jurusan Fisika FMIPA UNNES Semarang

Keywords: modified bitumen; cyclic natural rubber; cavity of bitumen

\section{PENDAHULUAN}

Aspal merupakan bahan pengikat (matriks) yang menyatukan semua agregat dalam pembuatan jalan raya. Sukirman (2012) menyatakan aspal digunakan sebagai material dalam perkerasan jalan berfungsi sebagai 1) bahan pengikat, memberikan ikatan yang kuat antara aspal dengan agregat dan antara sesama aspal; dan 2) bahan pengisi, mengisi rongga antar butir agregat dalam pori-pori yang ada di dalam butir agregat itu sendiri. Berdasarkan fungsi diatas terlihat bahwa aspal memiliki peranan yang sangat penting berkaitan dengan kualitas aspal. Kualitas aspal yang baik ber-

*Alamat Korespondensi:

Jalan Willem Iskandar Pasar V Medan, 20221

E-mail: winsyahputra@gmail.com potensi akan meningkatkan kualitas jalan raya dan demikian juga sebaliknya.

Baik tidak nya kualitas aspal ditentukan karaktersitik fisik campuran aspal dan agregatnya. Sukirman (2012) menyatakan bahwa karakteristik fisik campuran yang harus dimiliki aspal yaitu :

1. Stabilitas merupakan kemampuan perkerasan jalan menerima beban lalu lintas tanpa terjadi perubahan bentuk tetap seperti gelombang, alur, dan bleeding.

2. Durabilitas merupakan kemampuan beton aspal menerima repetisi beban lalu lintas seperti berat kendaraan, gesekan antara roda kendaraan dan permukaan jalan, serta menahan keausan akibat pengaruh cuaca dan iklim, seperti udara, air, atau perubahan temperatur yang dipengaruhi 
oleh tebalnya film atau selimut aspal, banyaknya rongga dalam campuran, kepadatan dan kedap airnya campuran.

3. Fleksibilitas adalah kemampuan beton aspal untuk menyesuaikan diri akibat penurunan fondasi atau tanah dasar tanpa terjadi retak.

4. Fatique resistance adalah kemampuan beton aspal menerima lendutan berulang akibat repetisi beban lalulintas, tanpa terjadinya kelelahan berupa alur dan atau retak. Hal ini dapat dicapai jika menggunakan kadar aspal yang tinggi

5. Skid resistance (kekesatan) adalah kemampuan permukaan beton aspal memberikan gaya gesek pada roda kendaraan sehingga kendaraan tidak tergelincir ataupun slip terutama pada kondisi basah.

6. Impermeabilitas (kedap air) adalah kemampuan beton aspal untuk tidak dapat dimasuki air ataupun udara ke dalam lapisan beton aspal. Jumlah rongga yang tersisa setelah beton aspal dipadatkan dapat menjadi indikator kekedapan campuran.

7. Workability adalah kemampuan campuran beton aspal untuk mudah dihamparkan dan dipadatkan. Faktor yang mempengaruhi adalah viskositas aspal, kepekaan terhadap temperatur, dan gradasi serta kondisi agregat.

Dari karakteristik fisika campuran aspal terlihat bahwa salah satu faktor yang mempengaruhi kualitas campuran aspal adalah rongga (pori) campuran aspal.

Rongga pada campuran aspal dan agregat merupakan salah satu penyebab kerusakan jalan raya. Rongga aspal yang besar akan mengakibatkan air mudah masuk melalui pori campuran aspal dan agregat sehingga ikatan aspal dan agregatnya menjadi lemah. Lemahnya ikatan aspal ini mengakibatkan jalan cepat rusak.

Harseno dan Daryanto (2008) menyatakan bahwa ukuran rongga mempengaruhi cepat lambatnya aliran air. Air yang melewati pori-pori akan membawa partikel-partikel aspal sehingga partikel-partikel aspal yang terbawa merupakan pembesaran ruang pori diantara butiran aspal. Hal ini akan menyebabkan debit air yang mengalir semakin besar dan volume aspal akan berkurang. Berkurangnya volume aspal akan mempengaruhi kondisi jalan disekitarnya, terutama terbentuknya banyak lubang

Parameter rongga pada pengujian marshall campuran aspal adalah VMA (void mix aspalt), VFA (void filled with aspalt), VIM (vodi in mix). VMA adalah Volume rongga antar butir agregat beton aspal padat. VFA adalah volume rongga yang dapat terisi oleh aspal. Sedangkan VIM adalah volume pori yang tersisa setelah campuran beton aspal dipadatkan.

Berbagai modifikasi aspal telah dilakukan untuk mengurangi ukuran rongga aspal. Rianung (2007) melakukan kajian laboratorium pengaruh bahan tambah gondorukem pada asphalt concrete-binder course (AC-BC) tehadap nilai propertis marshall dan durabilitas. Hasil penelitian menunjukkan bahwa masih terdapat rongga yang mengakibatkan air mudah masuk ke dalam campuran aspal.

Rondonuwu F, et al, (2013) telah melakukan penelitian tentang pengaruh sifat fisik agregat terhadap rongga dalam campuran beraspal panas. Hasil penelitian berat jenis bulk dan berat jenis apparent agregat yang nilainya semakin besar menghasilkan nilai VIM yang semakin rendah.

Kumalawati, Tri \& Mastaram, (2013) juga telah melakukan penelitian tentang pengaruh penggunaan abu batu apung sebagai pengganti filler untuk campuran aspal. Pembahasan penelitian menunjukkan bahwa penambahan abu batang berdampak pada peningkatan nilai VMA, penurunan nilai VIM dan peningkatan nilai VFB yang berdampak pada rongga aspal.

Material baru yang memungkinkan dicoba untuk dijadikan campuran dalam pembuatan aspal adalah karet alam siklik (cycllic natural rubber). Karet alam siklik merupakan salah satu bentuk karet alam yang dimodifikasi dengan cara pemanasan menggunakan katalis asam. Sifat karet alam siklik berbeda dengan karet alam asalnya. Kelebihan karet alam siklik diantaranya adalah tahan terhadap daya gosok dan mempunyai daya rekat yang lebih baik. Penggunaan utama karet alam siklik adalah sebagai bahan baku pembuatan cat, pelapis dan perekat (Chusna, 2002). Ritonga, Wiryosentono \& Nasruddin (2013) telah melakukan penelitian tentang potensi karet alam siklik dijadikan sebagai bahan modifikasi aspal. Hasil penelitian menunjukkan bahwa campuran aspal dengan karet alam siklik memenuhi persyaratan fisik aspal yang dipersyaratkan oleh Standar Nasional Indonesia (SNI).

Penelitian ini dilakukan untuk memperbaiki kelemahan campuran aspal dan agregatnya. Penelitian bertujuan untuk mengetahui pengaruh karet alam siklik terhadap rongga aspal. Diharapkan dengan menambahkan karet alam siklik akan dapat mengurangi ukuran 
rongga campuran aspal sehingga kualitas jalan raya bisa lebih baik lagi.

\section{METODE}

Penelitian ini dilakukan di laboratorium Teknik Sipil Politeknik Negeri Medan. Alat yang digunakan dalam penelitian ini adalah penetration test, termometer, pengatur waktu, bak perendam (water bath), cincin (terbuat dari bahan kuningan), bola baja, sumber pemanas (heater), cetakan daktilitas kuningan, mesin uji daktilitas, piknometer, bejana gelas, pengatur suhu, neraca analitik, oven, mixer, sedangkan bahan yang digunakan adalah aspal pen 60-70 dan karet alam siklik.

Tahapan pertama yang dilakukan pada penelitian ini adalah melakukan pengujian sifat fisik aspal terhadap aspal murni (sampel 1). Selanjutnya dilakukan pembuatan aspal modifikasi. Aspal modifikasi dirancang dengan mencampur aspal pen 60-70, asam akrilat dan benzoil peroksida ke dalam beaker, dipanaskan selama 30 menit pada suhu $90^{\circ} \mathrm{C}$, dan 180 rpm sampai meleleh. Perlakuan yang sama juga dilakukan dengan variasi campuran aspal murni, karet alam siklik, asam akrilat dan BPO dengan komposisi sampel pada Tabel 1.

Hasil penyampuran aspal dan bahan lainnya sesuai komposisi pada Tabel 1 diatas disebut sebagai aspal modifikasi. Terhadap aspal modiifkasi dilakukan pengujian sifat fisik aspal sesuai dengan SNI (Departemen Pekerjaan Umum, 2005). Pengujian sifat fisik aspal yang meliputi uji penetrasi, uji titik lembek, uji daktilitas, uji berat jenis, uji penurunan/kehilangan berat dan uji penetrasi setelah penurunan berat dari aspal yang telah termodifikasi menurut SNI.

Tahapan penelitian selanjutnya adalah melakukan pembuatan benda uji. Pembuatan benda uji dilakukan dengan menyampurkan pasir (agregat halus) dan kerikil (agregat kasar) dengan aspal modifikasi. Kadar aspal optimum yang digunakan $6 \%$. Benda uji yang dibuat se- banyak 5 (lima) benda uji yang mewakili setiap sampel aspal modifikasi. Setelah pembuatan benda selesai dilakukan, tahapan selanjutnya adalah melakukan pengujian marshall benda uji. Pengujian Marshal adalah metode pengujian laboratorium untuk bahan dasar perkerasan yang meliputi pengujian karakteristik campuran dan perencanaan kadar aspal optimum. Pengujian ini menghasilkan sejumlah data Marshall properties dan terdiri dari Stabilitas, Flow, VMA, VIM, VFA, dan Marshall Quotient (MQ) (Misbah, 2013). Parameter rongga pada pengujian marshall campuran aspal adalah VMA, VFA, VIM. Diagram alir penelitian dapat dilihat pada Gambar 1.

\section{HASIL DAN PEMBAHASAN}

Tahapan pertama pada penelitian ini adalah melakukan pengujian persyaratan fisik aspal terhadap aspal murni yaitu aspal tipe Iran pen 60/70 (sampel 1). Pengujian persyaratan fisik aspal meliputi uji penetrasi, uji titik lembek, uji daktilitas, uji berat jenis,uji penurunan berat, dan uji penetrasi setelah penurunan berat dari aspal yang telah termodifikasi menurut SNI. Hasil pengujian persyaratan fisik aspal murni dapat dilihat pada Tabel 2.

Hasil pengujian persyaratan fisika pada tabel 2 menunjukkan bahwa aspal murni yang digunakan dalam penelitian merupakan aspal pen 60/70. Hal ini disimpulkan dari kesesuaian antara hasil pengujian dengan SNI yang telah ditetapkan.

Tahapan penelitian selanjutnya adalah melakukan pembuatan aspal modifikasi. Aspal modifikasi dibuat dengan menambahkan karet alam siklik kedalam aspal murni. Setalah pembuatan aspal modifikasi selesai, dilakukan pengujian persyaratan fisik aspal terhadap aspal modifikasi. Pengujian persyaratan fisik aspal meliputi uji penetrasi, uji titik lembek, uji daktilitas, uji berat jenis,uji penurunan berat, dan uji penetrasi setelah penurunan berat dari aspal yang telah termodifikasi menurut SNI.

Tabel 1. Komposisi Campuran Sampel Penelitian

\begin{tabular}{ccccccccc}
\hline \multirow{2}{*}{ Sampel } & \multicolumn{2}{c}{ Aspalt } & \multicolumn{2}{c}{ CNR } & \multicolumn{2}{c}{ Asam Akrilat } & \multicolumn{2}{c}{ BPO } \\
\cline { 2 - 9 } & $\mathrm{g}$ & $\mathrm{phr}$ & $\mathrm{g}$ & $\mathrm{phr}$ & $\mathrm{ml}$ & $\mathrm{phr}$ & $\mathrm{g}$ & $\mathrm{mr}$ \\
\hline 1 & 2000 & 100 & 0 & 0 & 0 & 0 & 0 & 0 \\
2 & 2000 & 100 & 20 & 1 & 5 & 0.25 & 0.336 & 0.05 \\
3 & 2000 & 100 & 40 & 2 & 5 & 0.25 & 0.336 & 0.05 \\
4 & 2000 & 100 & 60 & 3 & 5 & 0.25 & 0.336 & 0.05 \\
5 & 2000 & 100 & 80 & 4 & 5 & 0.25 & 0.336 & 0.05 \\
\hline
\end{tabular}




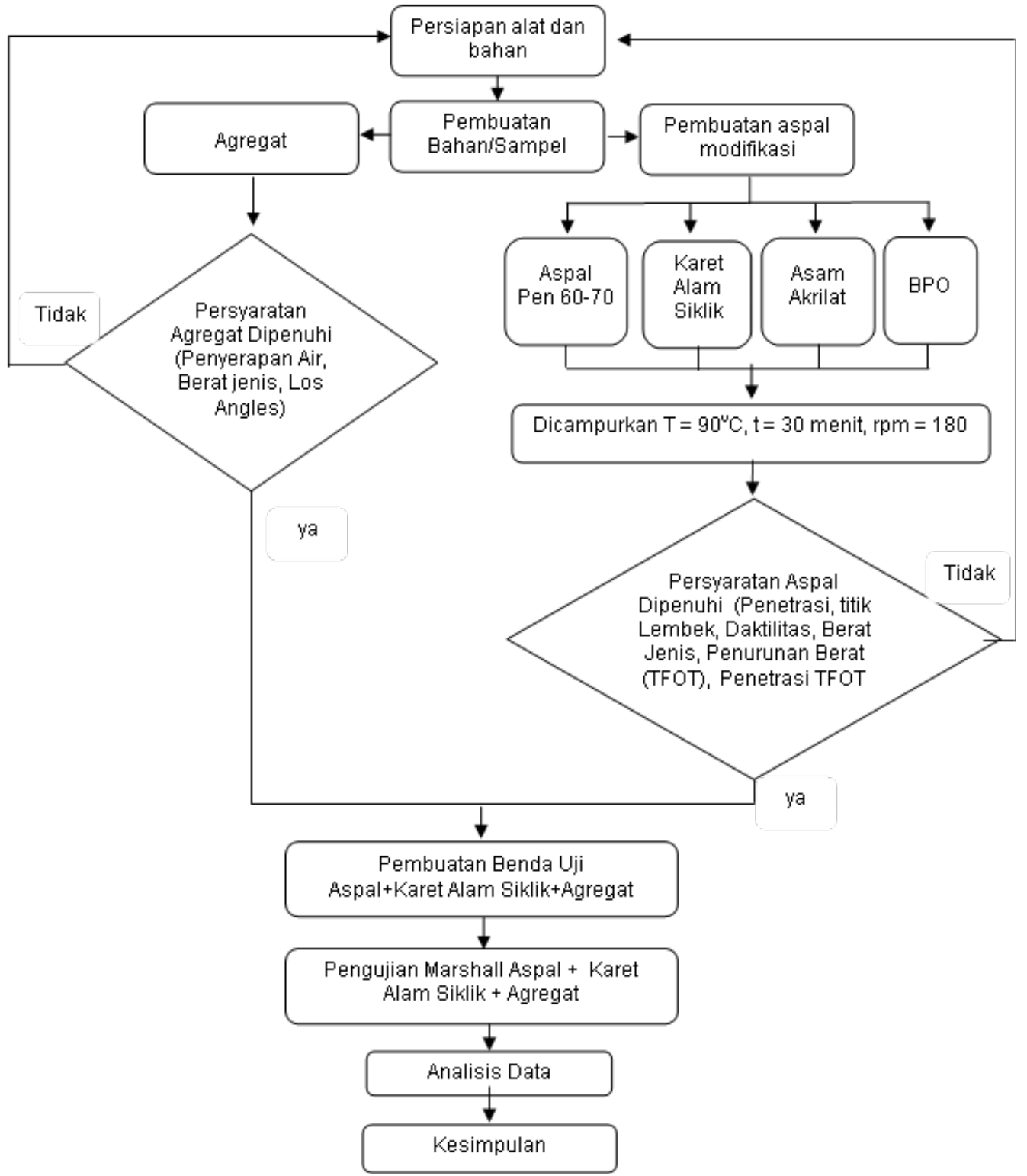

Gambar 1. Diagram alir penelitian

Tabel 2. Hasil pengujian persyaratan fisik aspal murni

\begin{tabular}{lccc}
\hline Jenis Pengujian & Sampel & SNI & Ket \\
\hline Penetrasi (mm) & 72.50 & $60-79$ & Memenuhi \\
Titik lembek aspal $\left({ }^{\circ} \mathrm{C}\right)$, & 35.00 & $30-50$ & Memenuhi \\
Daktilitas (cm) & 110.00 & Min 100 & Memenuhi \\
Berat Jenis Aspal & 1.01 & Min 1,0 & Memenuhi \\
Kehilangan Berat (\%) & 1.00 & Min 1,0 & Memenuhi \\
Penetrasi setelah penurunan berat (\%) & 70.20 & Min 45 & Memenuhi \\
Daktilitas penurunan (\%) & 55.00 & Min 50 & Memenuhi \\
\hline
\end{tabular}

Data penelitian menunjukkan bahwa penambahan konsentrasi karet alam siklik pada aspal menggunakan compatibilizer asam akrilat dan benzoil peroksida memberikan pen-

garuh terhadap sifat fisik aspal. Penambahan konsentrasi karet alam siklik menurunkan nilai penetrasi aspal menjadi Pen 40/50 yang sebelumnya memiliki Pen 60/70. Dikarenakan nilai 
penetrasi menurun sehingga persyaratan sifat fisik aspal disesuaikan dengan SNI Pen 40/50. Hasil pengujian persyaratan fisik aspal modifikasi dapat dilihat pada Tabel 3.

Berdasarkan Tabel 3 terlihat bahwa penambahan konsentrasi karet alam siklik pada aspal modifikasi berdampak pada semakin rendahnya nilai penetrasi aspal. Penetrasi aspal merupakan tingkat kekerasan aspal yang dimaksudkan masuknya jarum penetrasi ukuran tertentu beban tertentu dan waktu tertentu kedalam aspal pada suhu tertentu. Jarum penetrasi yang digunakan berdiamater $1 \mathrm{~mm}$ dan beban 50 gr. Berat jarum dengan beban menjadi 100 gram. Pengujian dilakukan pada suhu $25^{\circ} \mathrm{C}$. Semakin tinggi nilai penetrasi, maka aspal semakin lembek dan sebaliknya. Penambahan karet alam siklik pada aspal mengakibatkan nilai penetrasi aspal menjadi semakin kecil yang berarti aspal menjadi lebih keras.

Penambahan konsentrasi karet alam siklik juga berdampak pada peningkatan nilai titik lembek aspal modifikasi. Peningkatan nilai titik lembek berarti aspal semakin keras dan sebaliknya. Hasil pengujian titik lembek ini masih selaras dengan hasil pengujian penetrasi aspal yang menunjukkan aspal menjadi lebih keras. Pengerasan aspal ini dimungkinkan karena menguatnya ikatan antar partikel aspal yang diakibatkan fungsi karet alam siklik yang dapat merekatkan ikatan antar partikel. Keadaan ini juga sesuai dengan penyataan Palupi, et al (2008) yang menyatakan bahwa karet alam si- klik dapat berfungsi sebagai resin yang dapat menjadi perekat dalam campuran bahan.

Hasil pengujian persyaratan fisik aspal pada tabel 3 menunjukkan bahwa penambahan konsentrasi karet alam siklik sampai 4 phr pada aspal masih memenuhi persyaratan fisik aspal. Dengan demikian karet alam siklik dapat digunakan sebagai bahan campuran aspal.

Tahapan selanjutnya adalah pembuatan benda uji. Benda uji yang digunakan sebanyak 5 benda uji. Pembuatan benda uji dilakukan dengan menyampurkan pasir (agregat halus) dan kerikil (agregat kasar) dengan aspal modifikasi. Setelah pembuatan benda uji selesai dilakukan, tahapan selanjutnya adalah melakukan pengujian marshall benda uji. Pengujian marshall dilakukan untuk mengetahui ukuran rongga campuran aspal dan agregatnya. Parameter rongga pada pengujian marshall campuran aspal adalah VMA, VFA, VIM seperti pada Tabel 4.

Hasil pengujian marshall pada Tabel 4 menunjukkan bahwa penambahan konsentrasi karet alam siklik berpengaruh terhadap nilai VMA aspal modifikasi. Pengaruh yang terjadi adalah semakin besar konsentrasi karet alam siklik yang diberikan berdampak pada semakin kecilnya nilai VMA aspal. Nilai VMA aspal murni (sampel 1) sebesar VMA 15,52\%, sedangkan penambahan konsentrasi karet alam siklik 4 phr (sampel 5) memiliki nilai VMA 15,17\%. Penambahan karet alam siklik sampai $4 \mathrm{phr}$ (sampel 5) masih memenuhi standar VMA

Tabel 3. Hasil pengujian persyaratan fisik aspal modifikasi

\begin{tabular}{|c|c|c|c|c|c|c|}
\hline \multirow{2}{*}{ Jenis Pengujian } & \multicolumn{4}{|c|}{ Sampel } & \multirow{2}{*}{ SNI } & \multirow{2}{*}{ Ket } \\
\hline & 2 & 3 & 4 & 5 & & \\
\hline Penetrasi (mm) & 53.17 & 51.83 & 47.00 & 46.50 & $40-59$ & Memenuhi \\
\hline Titik lembek aspal $\left({ }^{\circ} \mathrm{C}\right)$, & 39.50 & 42.00 & 42.50 & 44.50 & $30-50$ & Memenuhi \\
\hline Daktilitas (cm) & 120.00 & 150.00 & 150.00 & 150.00 & Min 100 & Memenuhi \\
\hline Berat Jenis Aspal & 1.02 & 1.02 & 1.03 & 1.09 & Min 1,0 & Memenuhi \\
\hline Kehilangan Berat (\%) & 2.15 & 2.32 & 2.34 & 2.40 & Min 1,0 & Memenuhi \\
\hline $\begin{array}{l}\text { Penetrasi setelah penurunan berat } \\
(\%)\end{array}$ & 50.30 & 49.00 & 47.59 & 45.08 & Min 45 & Memenuhi \\
\hline Daktilitas penurunan (\%) & 60.00 & 75.00 & 75.00 & 75.00 & Min 50 & Memenuhi \\
\hline
\end{tabular}

Tabel 4. Hasil pengujian parameter rongga aspal modifikasi

\begin{tabular}{ccccccc}
\hline \multirow{2}{*}{ Paremater Aspal } & \multicolumn{7}{c}{ Sampel } & \multirow{2}{*}{ Spesifikasi } \\
\cline { 2 - 6 } & 1 & 2 & 3 & 4 & 5 & \\
\hline VMA & 15,52 & 17,26 & 16,07 & 15,8 & 15,17 & $\min 15$ \\
VIM & 3,65 & 5,41 & 4,27 & 3,84 & 2,88 & $3-5$ \\
VFA & 76,48 & 68,72 & 73,54 & 75,76 & 81,34 & min. 65 \\
\hline
\end{tabular}


aspal yaitu minimal 15\%. Hubungan antara penambahan konsentrasi karet alam siklik terhadap nilai VMA aspal modifikasi dapat dilihat pada Gambar 2.

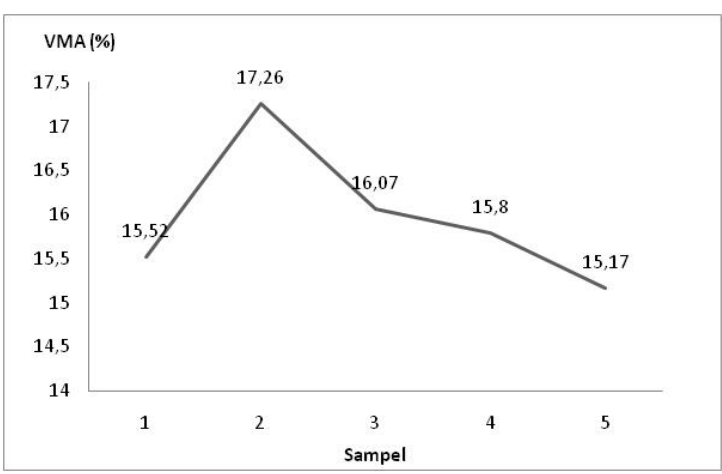

Gambar 2. Grafik hubungan antara penambahan konsetrasi karet alam siklik terhadap nilai VMA aspal

Penambahan konsentrasi karet alam siklik berpengaruh terhadap nilai VIM aspal modifikasi. Hubungan antara penambahan konsentrasi karet alam siklik terhadap nilai VIM aspal modifikasi dapat dilihat pada Gambar 3.

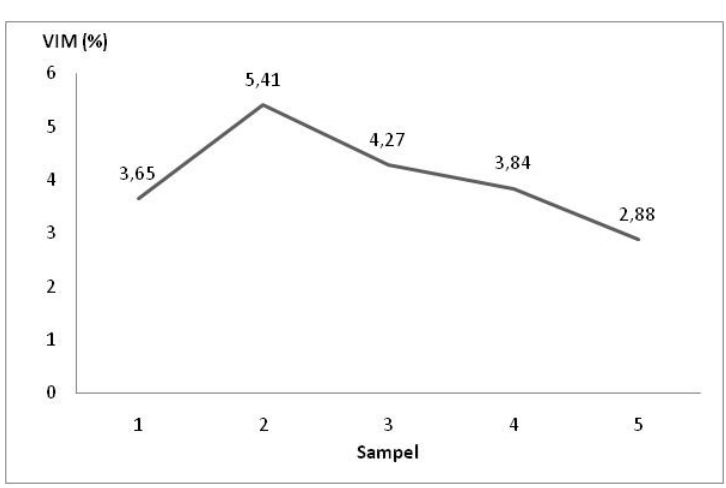

Gambar 3. Grafik hubungan antara penambahan konsentrasi karet alam siklik terhadap nilai VIM aspal

Gambar 3 menunjukkan bahwa semakin besar penambahan konsentrasi karet alam siklik yang diberikan berdampak pada semakin kecilnya nilai VIM aspal. Nilai VIM aspal murni (sampel 1) sebesar 3,65\%, sedangkan penambahan konsentrasi karet alam siklik 3 phr (sampel 4) memiliki nilai VIM 3,84\%. Penambahan konsentrasi karet alam siklik sampai 3 phr (sampel 4) masih memenuhi standar VIM aspal yaitu 3-5 \%. Penambahan konsentrasi karet alam siklik sebesar 4 phr memiliki nilai VIM 2,88\% sehingga tidak memenuhi standar VIM aspal.

Penambahan konsentrasi karet alam siklik juga berpengaruh terhadap nilai VFA aspal modifikasi. Hubungan antara penambahan konsentrasi karet alam siklik terhadap nilai VFA aspal modifikasi dapat dilihat pada Gambar 4.

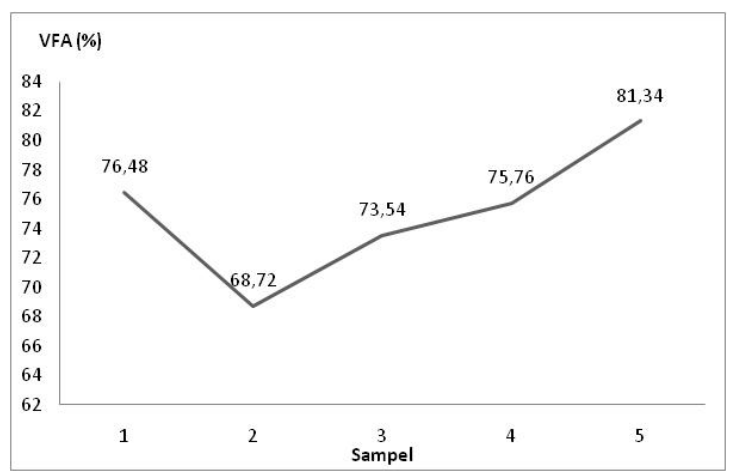

Gambar 4. Grafik hubungan antara penambahan konsentrasi karet alam siklik terhadap VFA aspal

Gambar 4 menunjukkan bahwa semakin besar konsentrasi karet alam siklik yang diberikan berdampak pada semakin besarnya nilai VFA aspal. Nilai VFA sampel 1 (aspal murni) memiliki nilai VFA 76,48 \%, sedangkan penambahan konsentrasi karet alam siklik 4 phr (sampel 5) memiliki nilai VFA 81,34\%. Keseluruhan sampel memenuhi standar nilai VFA aspal yaitu minimal $65 \%$.

Penambahan konsentrasi karet alam siklik pada campuran aspal mempengaruhi rongga aspal modifikasi. Data menunjukkan penambahan konsentrasi karet alam siklik menyebabkan nilai VMA dan VIM semakin kecil dan nilai VFA semakin besar. Berdasarkan standar semakin kecilnya nilai VMA dan semakin besarnya nilai VFA menunjukkan semakin kecilnya rongga aspal. Nilai VIM aspal modifikasi juga mengalami perubahan seiring dengan penambahan karet alam siklik. Tetapi tidak semua sampel memenuhinya. Sampel 1 sampai sampel 4 masih memenuhi standar VIM yang ditetapkan, dan sampel 5 tidak memenuhi standar yang telah ditentukan. Penambahan karet alam siklik berarti berdampak pada rongga aspal.

Hasil dan pembahasan penelitian menunjukkan bahwa dua parameter (VMA dan VIM) mengalami penurunan persentase, sedangkan satu parameter (VFA) mengalami kenaikan persentase. Keadaan ini menunjukkan bahwa penambahan konsentrasi karet alam siklik dapat mempengaruhi VMA, VIM dan VFA dengan pola hampir linier berbanding terbalik.

Kenaikan nilai VFA serta menurunnya VMA dan VIM menyebabkan densitas semakin 
turun. Menurunnya densitas (kerapatan antar molekul) diakibatkan oleh terbentuknya rantai yang lebih besar. Terbentuknya rantai yang lebih besar menyebabkan semakin besarnya jarak antara rantai molekul karet alam siklik dan aspal. Terjadinya ikatan antara aspal dan karet alam siklik di satu sisi meningkatkan titik lembek aspal, akan tetapi menyebabkan semakin membesarnya pori-pori antara rantai/ molekulnya yang ditunjukkan dengan meningkatnya harga VFA dan menurunnya VIM dan VMA.

Besarnya rongga kemungkinan disebabkan oleh semakin besarnya berat jenis aspalkaret alam siklik. Perpaduan berat jenis aspal dan berat jenis karet mengakibatkan berat jenis aspal-karet alam siklik lebih besar (berat jenis ,karet alam siklik $1 \mathrm{gr} / \mathrm{ml}$ dan berat jenis karet alam sekitar $2 \mathrm{gr} / \mathrm{ml}$ ). Besarnya rongga ini berdampak pada menurunnya karakteristik durabilitas (keawetan), fatique resistence (ketahanan terhadap kelelehan) dan Impermeabilitas (kedap air). Rongga yang lebih besar menyebabkan air dan udara lebih mudah masuk kedalam campuran aspal sehingga ikatan campuran aspal dengan agregatnya menjadi lemah. Lemahnya ikatan antara aspal dengan agregatnya menyebabkan jalan tidak tahan lama atau cepat rusak ketika digunakan.

Salah satu penelitian tentang rongga aspal telah dilakukan oleh Siregar, Ritonga \& Arunika, (2014). Penelitian dilakukan dengan memanfaatkan natural rubber sebagai bahan modifikasi aspal. Hasil penelitiannya menunjukkan bahwa penambahan natural rubber meningkatkan nilai VIM dan VMA serta menurunkan nilai VFA. Sedangkan dalam penelitian ini digunakan karet alam siklik sebagai bahan pencampuran aspal dan hasil penelitian menunjukkan bahwa penambahan karet alam siklik akan menurunkan nilai VIM dan VMA dan menaikkan nilai VFA. Perbedaan hasil kedua penelitian ini kemungkinan disebabkan perbedaan fungsi dan bentuk fisik karet alam siklik dan natural rubber yang mengakibatkan perbedaan struktur campuran aspal.

\section{SIMPULAN}

Berdasarkan hasil pengujian terhadap sifat fisik persyaratan aspal, diperoleh informasi bahwa karet alam siklik dapat dijadikan sebagai bahan campuran aspal modifikasi. Setelah dilakukan pengujian marshall diperoleh informasi bahwa penambahan karet alam siklik berpengaruh terhadap rongga aspal modifika- si. Penambahan konsentrasi karet alam siklik menyebabkan nilai VMA dan VIM semakin kecil dan nilai VFA semakin besar. Berdasarkan standar semakin kecilnya nilai VMA dan semakin besarnya nilai VFA menunjukkan rongga aspal modifikasi semakin kecil. Rongga aspal yang semakin kecil menyebabkan air lebih sulit masuk ke campuran aspal dan agregatnya sehingga kualitas jalan menjadi lebih baik.

Untuk pengembangan penelitian ini lebin lanjut disarankan untuk melakukan kajian yang dapat mengurangi kelemahan modifikasi aspal-karet alam siklik seperti menambahkan filler lain kedalam aspal yang berfungsi untuk mengisi rongga yang terdapat pada aspal dan menggunakan beberapa jenis plastisizer minyak pelumas ke dalam campuran aspal-karet alam siklik dan agregat.

\section{UCAPAN TERIMA KASIH}

Ucapan terimakasih ditujukan kepada Direktorat Penelitian dan Pengabdian Kepada Masyarakat Ditjen DIKTI yang telah mendanai penelitian ini melalui skema penelitian hibah bersaing Tahun Anggaran 2015 sesuai kontrak pelaksanaan penelitian Nomor: 064/SP2H/PL/ Dit.Litabmas/ll/2015, tanggal 5 Februari 2015.

\section{DAFTAR PUSTAKA}

Chusna, S. F.(2002). Kajian Pembuatan Karet Siklo Berbobot Molekul Rendah. Tesis. Bogor: Program Pasca Sarjana Institut Pertanian Bogor.

Departemen Pekerjaan Umum. (2005). Spesifikasi Umum Bidang Jalan dan Jembatan, Jakarta

Harseno, E. \& Daryanto, E. (2008). Tinjauan Tinggi Tekanan Air di Bawah Bendung dengan Turap dan Tanpa Turap pada Tanah Berbutir Halus. Majalah IImiah UKRIM Yogyakarta, 8(2), 1-15.

Kumalawati, A., Sir, T. M., \& Mastaram, Y. (2013). Analisis Pengaruh Penggunaan Abu Batu Apung Sebagai Pengganti Filler Untuk Campuran Aspal. Jurnal Teknik Sipil, 2(2), 191200.

Misbah. (2013). Pengaruh Variasi Kadar Agregat Kasar Terhadap Nilai Karakteristik Campuran Panas Aspal Agregat (AC-BC) Dengan Pengujian Marshall. Jurnal Momentum, 17(1), 84-90.

Palupi, N. P., Sailah, I., Syamsu, Y., \& Pandji, C. (2008). Karakterisasi Perekat Siklo Karet Alam. Jurnal Teknologi Pertanian, 4(1), 1924.

Rianung, S. (2007). Kajian Laboratorium Pengaruh Bahan Tambah Gondorukem pada Asphalt Concrete-Binder Course (AC-BC) Tehadap Nilai Propertis Marshall dan Durabilita. Tesis 
Semarang: Program Pascasarjana Fakultas Teknik Universitas Diponegoro.

Ritonga, W., Wiryosentono, B., \& Nasruddin. (2013). Study Persyaratan Fisik Aspal Modifikasi Dengan Pemanfaatan Karet Alam Siklik (Cyclic Natural Rubber). Jurnal Einstein, 1(1), 42-47.

Rondonuwu, F., Kaseke, O. H., Rumayar, A. L. E., \& Manoppo, M. R. E. (2013). Pengaruh sifat fisik agregat terhadap rongga Dalam campuran beraspal panas. Jurnal Sipil Statik.
1(3), 184-189.

Siregar, A. M., Ritonga, W., \& Arunika, S. (2015), Analisis Rongga Pada Aspal Iran Pen 80/100 Termodifikasi Dengan Karet Alam (Natural Rubber) Pada Campuran Asphalt Concrete - Wearing Course (AC-WC), disampaikan pada Semirata PKS PTN Wilayah Barat Tahun 2015 di Universitas Tanjungpura Pontianak Kalimantan Barat, 6-8 Mei 2015.

Sukirman, S. (2012). Beton Aspal Campuran Panas. Edisi Kedua. Bandung: Itenas. 